\title{
Solute Carrier Family 2, Facilitated Glucose Transporter Member 1
}

National Cancer Institute

\section{Source}

National Cancer Institute. Solute Carrier Family 2, Facilitated Glucose Transporter

Member 1. NCl Thesaurus. Code C17585.

Solute carrier family 2, facilitated glucose transporter member 1 (492 aa, $\sim 54 \mathrm{kDa}$ ) is encoded by the human SLC2A1 gene. This protein plays a role in glucose transport. 